\title{
Translation Quality of Liz's Expressive Utterances in Eat Pray Love Movie Based on the Techniques Applied
}

\author{
Irta Fitriana \\ \{irtafitriana@ fbs.unipdu.ac.id $\}$ \\ Universitas Pesantren Tinggi Darul Ulum, Jombang
}

\begin{abstract}
This study is about an analysis of translation techniques applied in translating expressive utterances and how its translation quality (accuracy, acceptance, and legibility level) as seen from the translation techniques used. It is a descriptive qualitative research. The data are all Liz's expressive utterances. After analysis, it is found that there are six kinds of expressive utterances stated. They are praising, thanking, complaining, apologizing, wishing and greetings. Related to the translation techniques used, there are literal translation, reduction, transposition, and modulation. The implementation of translation techniques produced accurate, acceptable and easily understood translations. Thus, it can be concluded that Liz's expressive utterances in Eat Pray Love movie have succeeded in maintaining the theme of the story including its characterization in the Indonesian translation.
\end{abstract}

Keywords: expressive, utterances, SL, TL, translation techniques, translation quality

\section{Introduction}

Learning expressive utterances is a kind of understanding pragmatics, especially speech act. It deals with the speaker's intention. Moreover, it learns how the language is used to communicate. It is about how to understand what the speaker means. In other words, what the intended meaning caught is the core of pragmatics. The intended meaning is according to appropriate circumstances containing when, where and what the circumstances. It accommodates components outside the language to have a meaning contribution to communication. According to Leech (1995:6) pragmatics is the study of utterances which has meaning in such situation. Thus, the utterances meaning should be considered based on the context.

Translation and pragmatics have a close correlation. It is about how the message delivered correctly and properly. In its development, pragmatics are often used as a new approach in translation. The application of pragmatic approach in translation that is widely applied is in utterances/ conversation/ speech since they have their own certain purpose delivered based on the specific speech situation including the speaker and hearer, context, aim, time and place.

Translating utterances is interesting. It concerns how the message or intended meaning transferred appropriately related to the context (speech situation). In its translation, it becomes very important because it involves understanding the context in order to the translation result appropriate to avoid misunderstanding. Hence, translation using pragmatics approach should 
not change the intention (illocution) of Source Language (SL) to Target Language (TL). Hence, there is not meaning distortion occurred.

One of the kinds of illocution is expressive utterances. According to Searle (1979) in Yule (1996:53-55) expressive utterances are acts that state what the speaker feels. It expresses the speaker's feeling about the situation (Pratiwi, 2017). There are several functions of expressive utterances such as congratulating, pardoning, apologizing, condoling, thanking, blaming, welcoming, worrying, forgiving, wishing, boasting, praising and etc. These functions are discussed in Eat Pray Love movie by Elizabeth Gilbert in term of translation technique and its impact towards translation quality.

Eat Pray Love is a successful and best seller movie in America. This movie was translated by Silamurti Nugroho and first printed in 2010. Eat Pray Love is about woman named Liz who struggles to achieve her happiness after divorcing. The story tells the journey of a woman in three countries. They are Italy, India and Indonesia. These countries are chosen because of its beauty and uniqueness. One of them is Indonesia. It is because Indonesia has a uniqueness, especially Bali island. It is a lovely and popular tourist resort in Indonesia. During the story, Bali is a last place Liz visited to. There, she finally gets her happiness and true love. (http://id.shvoong.com/books/movie-moviela/2172421-eat-pray-love-perjalanan-

mencari/\#ixzz2TFe3Cv2C). These are the inspiration and reason taken to do this research.

This research is also inspired by two previous research. The first related previous research is done by Hari Nugraha in 2019. He discussed the translation quality of expressive speech act found in a movie. His study was conducted to uncover the types of speech acts found and its translation quality (accuracy, acceptability, readability). The result of analysis showed that the translation indicated an accurate, acceptable translation. Thus, the readers can understand easily. The next previous research was done by Ardiana Nuraeni in 2008. Her research is to compare the translation of complaining utterances in a movie. Related to speech act, this research focuses on one of expressive functions to obtain the deep discussion.

As mentioned above, Eat Pray Love movie is about woman's struggles to get happiness after divorcing. Many problems with her husband and herself come to her life. It can be seen from many utterances there. This research is focused on expressive utterances of Liz Gilbert as the main character. Then, analyzing the translation techniques and the impacts towards the quality is also discussed. The results have significances in enriching reader's comprehension of techniques on translating expressive utterances.

\section{Literature Review \\ 2. 1 Translation}

Transmission of message in a language is called translation. In addition, the message is transferred well and stay equal without meaning distortion. Many propositions of translation definition come from some expert since the 1960s. Firstly, the proposition from Newmark (1988: 5). He stated that translation is about the process of text meaning rendition into another text in accordance with the author's intention. This statement implies that the core of translation is in the message or intention. Secondly, the consideration of translation is given by Nida and Taber. They proposed two important things in a process of translation: meaning and style. They stated that a good translation has these elements. The meaning should be similar and sounds natural in target text. The style here means the translation should have efforts to achieve the ideal level of equivalent match between in both SL and TL. From these two definitions, it can be concluded that translation a transmitting meaning and style from SL to TL ideally. In 
addition, the message transmitted without omitting the intention between the author to the readers as a means of communication.

\section{2 Translation Techniques}

Many translators have different ways in translating a text since they have their own ideology. They may apply distinctive techniques to translate. However, translation should be constant. In translating a text, a translator has to express the message of a language into another language. A translator should find the equivalences of SL transmitted into TL ideally and to avoid meaning distortion. A good translator is not only transmitting each word in SL into TL, but also transmitting the meaning without changing the message.

Some translation techniques may be chosen and applied by a translator. The techniques are selected appropriately to give a good translation in order to be well understood by the readers. It means that the meaning is transmitted properly and natural. Translation technique is a realization of a translator's decision in a process of creating translation result. As Molina and Albir (2002) in Fitriana (2013: 16) stated an opinion regarding translation techniques as procedure to do analysis and classification of how translation equivalence successful. They released eighteen translation techniques that can be used as a reference to translate. They are: Amplification (Addition), Adaptation, Borrowing, Compensation, Calque, Description, Established Equivalence, Discursive Creation, Generalization, Linguistic Compression, Linguistic Amplification, Literal Translation, Particularization, Modulation, Reduction, Transposition, Substitution, and Variation. These various techniques can be used by translators to translate any product or text.

\section{3 Translation Quality}

The main purpose of translating activity is to get translation quality (achievement of accuracy, readability, and acceptability). This is closely related to the reader as the client results of the translation. Therefore, a translator must determine in advance who the prospective readers of the translation is and the purpose of it. When the target readers cannot understand the contents or the meaning, the translation means failed.

Translation quality is determined by gauging three elements. They are readability, accuracy, and acceptability. Hence, the meaning translated should be accurate, acceptable and easy to understand by the readers. A good translation has the best degree of each component. These three elements are the parameters to measure the quality of translation quality that are interrelated with one another. As Nababan (2008) states that the strength and weakness of translation product is based on the assessment of translation quality including accuracy, acceptability and readability. Accuracy is a term used in evaluating the equivalence between SL and TL. Accuracy becomes the basic principle of translation, so it must be the main focus of the translator. In other words, the message transmitted must be conveyed the same meaning.

Secondly is acceptability. Nababan (2012) stated that acceptability becomes an important aspect of a translation. It determines the appropriateness of a translation seen from the Target Language (TL). Acceptability in translation quality assessment can be called a natural translation. is related to the style. The translation should be appropriate in writing rules in TL. Besides, it should give appropriateness in term of norm and culture. Finally, the translation sounds natural.

Thirdly is readability. It is about the degree to which a translated text can be easily understood. A text translation has a high level of readability if the text is easily understood by readers of TL text. Here the role of the readers is very necessary in determining the level of 
readability. The table below shows Quality Translation Assessment including accuracy, acceptability, and readability (Adapted from Nababan, 2010: 3)

Table 2.3.1. Scales of Translation Accuracy

\begin{tabular}{|c|c|l|}
\hline $\begin{array}{c}\text { Translation } \\
\text { Category }\end{array}$ & Scale & \multicolumn{1}{c|}{ Indicator } \\
\hline Accurate & 3 & $\begin{array}{l}\text { The meaning of words, phrases, clauses, or sentences in the source text } \\
\text { is conveyed accurately in the target text. There are no distortions in } \\
\text { meaning. }\end{array}$ \\
\hline Less Accurate & 2 & $\begin{array}{l}\text { The meaning of words, phrases, clauses, or sentences in the source text } \\
\text { is mostly conveyed accurately in the target text. However, there are still } \\
\text { distortions in meaning (ambiguity or reduction that distracts the } \\
\text { meaning). }\end{array}$ \\
\hline Inaccurate & 1 & $\begin{array}{l}\text { The meaning of words, phrases, clauses, or sentences in the source text } \\
\text { is not conveyed accurately in the target text. }\end{array}$ \\
\hline
\end{tabular}

Table 2.3.1. Scales of Translation Acceptability

\begin{tabular}{|l|c|l|}
\hline $\begin{array}{c}\text { Translation } \\
\text { Category }\end{array}$ & Scale & \multicolumn{1}{c|}{ Indicator } \\
\hline Acceptable & 3 & $\begin{array}{l}\text { The translation sounds natural; the words, phrases, clauses, and } \\
\text { sentences of the source text are appropriate with the target language"s } \\
\text { principles. }\end{array}$ \\
\hline $\begin{array}{l}\text { Less } \\
\text { Acceptable }\end{array}$ & 2 & $\begin{array}{l}\text { The translation sounds natural; but there are still problems with the } \\
\text { dictions or grammar. }\end{array}$ \\
\hline Unacceptable & 1 & $\begin{array}{l}\text { The translation sounds unnatural; the words, phrases, clauses, and } \\
\text { sentences used are inappropriate with the target language"s principles. }\end{array}$ \\
\hline
\end{tabular}

Table 2.3.1. Scales of Translation Acceptability

\begin{tabular}{|l|c|l|}
\hline $\begin{array}{c}\text { Translation } \\
\text { Category }\end{array}$ & Scale & \multicolumn{1}{c|}{ Indicator } \\
\hline Readable & 3 & The translation is very easy to understand \\
\hline Less Readable & 2 & $\begin{array}{l}\text { The translation is quite easy to understand; the readers need to read } \\
\text { some parts more than once in order to understand the translation. }\end{array}$ \\
\hline Unreadable & 1 & The translation is difficult to understand. \\
\hline
\end{tabular}

\subsection{Expressive Utterances}

Yule (2006: 93) argues that in expressive speech acts there are statements that describe what is felt by the speaker. This speech act reflects the psychological statements of the speaker of a situation. In addition, expressive utterance is speech that is intended to reveal the speaker's expression. This speech act tends to be fun because it is intrinsically polite, except expressive utterances like condemning, apologizing and blaming. According to Yule (2006), expressive utterances has several functions such as thanking, expecting, complaining, revering, greeting, forgiving, rejecting, praising, insulting, and cursing. 


\section{Method}

This research applies descriptive qualitative research. As Sutopo (2006) stated that descriptive qualitative research is aimed to understand the problems individually for academics and to describe the problems in detail. The sequence includes collecting, classifying, analyzing and concluding. This is characterized as product-oriented translation research since both SL and TL have been existed.

There are the main data and additional data used in this discussion. The main data are all expressive utterances by Liz as the main character in the movie. There are 36 data of expressive utterances from whole utterances delivered by Liz. Besides, the next main data is the questionnaires of translation quality assessment. The secondary data are Eat Pray Love movie's review and information of the author. The data will be written with the code. The code consists of number of data and movie title, for example 07-EPL. It indicates the data number 7 taken from Eat Pray Love movie. Then, there are three important cases to be discussed here such as kinds of expressive utterance's functions analysis, techniques of translation implemented and the measurement of and translation quality based on Nababan (2010)

\section{Results and Discussion}

After analysis, some findings are obtained. They are kinds of expressive utterances functions, kinds of translation techniques applied and estimation of translation quality.

\subsection{Functions of expressive utterances}

After doing analysis, this research notes about 36 data of expressive from whole types of illocutionary acts used by Liz Gilbert. There are 6 functions of expressive utterances found such as praising, thanking, complaining, apologizing, wishing and greetings. They are 18 data of praising, 10 data of thanking, 2 data of complaining, 2 data of apologizing, 2 data of wishing and 2 data of greetings. Based on Searle's theory, expressive is utterances involving psychological attitude of the speaker. Here are some functions of expressive utterances.

\subsubsection{Praising}

Praising utterances are the most found in Eat Pray Love movie uttered by Liz Gilbert. Here are totally 18 data found. Here are some examples:

a. Code: 09-EPL

Context:

Ian was a man whom Liz met during her travel in Italia. She thought that he was different from other men she met in her life.

SL : He's attractive, intelligent. It's been long time since I thought about liking anybody.

TL : Dia menarik, cerdas. Sudah lama sekali sejak saya menyenangi seseorang.

This is the expression of Liz's praising to a man she admires. His name is Ian. Praising function here is clearly seen from the words 'attractive' and 'smart'.

b. Code: 24-EPL

Context:

On her travelling in Italia, Liz met a man in a train. She believed that Italian men are friendly and polite.

SL : And you are gracious, just like all Italian men. 
TL : Dan kamu sangat ramah, seperti pria Italia lainnya.

This is a finding of praising utterance by Liz in Eat Pray Love movie. Liz expresses her praising to a man sitting next to her in a train. A man praises Liz, then Liz replies by praising him too through the word 'friendly'.

c. Code: $29-\mathrm{EPL}$

Context:

In India, Liz had ever seen a girl named Tutti. She was so cute and smart girl.

SL : I think you are a very good girl.

TL : Saya rasa kamu anak yang pandai.

It is Liz utterance to Tutti, a little girl she met. The girl is very smart. Liz expresses her praising to Tutti by saying "I think you are a very good girl,". The word indicating praising function here is the word 'good'.

\subsubsection{Thanking}

After analysis, it is found 10 data of expressive utterances of thanking. There are some examples of them:

a. Code: 11-EPL

Context: Iva was a good friend of Liz. She always supported Liz to overcome her life problems.

SL : Thank you, Iva. I appreciate your support.

TL : Terima kasih Iva. Saya menghargai dukunganmu.

Liz's utterance above is a kind of expressive utterance that is thanking. In this utterance, Liz says thank you to her friend, Iva for her support. It is categorized into thanking utterance because of the words 'thank you'.

b. Code: 19-EPL

Context:

Liz travelled to Venice by train. She was asleep and she didn't know that she had arrived at Venice. Then, a man waked her up. He waked her up shortly before arriving in Venice by rubbing his eyes and looking over at her from head to foot closely. It made Liz shy and thanks to his attention.

SL : A thousand thanks.

TL : Terima kasih.

In this utterance, Liz expresses her thanks to the guy sitting next to her in a train. It can be seen from the word 'thank' in that utterance.

c. Code: 21-EPL

Context:

Wayan was a woman whom Liz met in Bali. She was a famous masseur in Bali.

SL : Thank you, Wayan. You did a good job.

TL : Terima kasih, Wayan. Kamu telah melakukan pekerjaan yang bagus. 
Based on the context, Liz expresses her thanks to Wayan for having giving her a good massage. She felt relax and calm. Besides, some advices given made Liz quite quiet. Liz realized that she was not thankful to God for everything given to her life. This utterance shows thanking function of expressive utterance as clearly to be seen from the word 'thank you'.

\subsubsection{Complaining}

Complaining is one of expressive functions. After doing analysis, it is found 2 data of complaining as follow:

Code: 07-EPL

Context:

In a night, Liz prayed to God. She was whining about her household problems, especially her husband. She thought that her marriage could never be saved anymore.

SL : But it just destroys me to not be able to count on that affection when I need it.

TL : Tetapi hubungan ini menghancurkan saya ketika saya tidak dapat bergantung pada kasih sayang itu ketika saya membutuhkannya.

This utterance can be called as complaining utterance. It is shown by the word 'destroy'. Based on the context, it is uttered by Liz when she is praying. She delivers her sadness to God.

\subsubsection{Apologizing}

Some apologizing utterances are found in Liz's expressive utterances. There are 2 apologizing utterances found after analysis. The findings as follow:

Code: 17-EPL

Context:

Liz expressed her apology to Felipe, a man who loved her much. However, Liz need to solve all her marriage problem with Steven (her husband).

SL : I'm, sorry. That's was a little arrogant, wasn't it?

TL : Saya minta maaf. Saya terlalu sombong.

In this context, Liz express her apology to Felipe. Although she knows well that Felipe love her much, but Liz gives him less affection and attention. The word showing apology function here is the word 'sorry'.

\subsubsection{Wishing/ Hoping}

In this research, it is found 2 data of wishing utterances. Here is one of the findings:

Code: $30-E P L$

Context:

SL : I wish I could write a petition to God, asking for this thing to end.

TL : Saya berharap saya dapat menulis sebuah petisi kepada Tuhan, memintanya untuk mengakhiri semua ini.

This is a kind of expressive utterances, that is hoping/ wishing. Liz feels that the problems faced is quite hard and she wants to end her marriage. The word 'wish' shows wishing function of expressive utterances. 


\subsubsection{Greeting}

After analysis of expressive utterances, one of the functions is greeting. There are 2 data found categorized into greeting utterances. The example is below:

Code: 03-EPL

Context:

As a woman trying to defend her marriage, a strong struggle to make the life marriage and carrier is balance has been done by Liz. In her praying, he tries to speak with God as a friend.

SL : Hello, God. How are you? I'm Liz. It's nice to meet you.

TL : Halo Tuhan. Apa kabar? Saya Liz. Senang bertemu denganmu.

This utterance contains greeting. Liz always greet God in the beginning of her praying like shown by the word 'hello' and 'how are you'.

\subsection{Translation Techniques}

After doing analysis, there several techniques applied in translating expressive utterances in Eat Pray love movie. They are literal translation, reduction, transposition, and modulation. The most translation techniques applied is literal translation. From 36 expressive utterances, there are 19 data translated by using literal translation, 8 expressive utterances using reduction, 5 data of transposition, 4 data of modulation.

\subsubsection{Literal Translation}

Based on Molina and Albir in Fitriana (2013: 15) related to kinds of translation techniques, one of them is literal translation. is a way of translating each word expressed. It happens when the equivalence existed in two different languages. Here are the examples of the findings of literal translation.

a. Code: 10-EPL

Context:

In the late of night, while crying, Liz was expressing her feeling to God. She felt that her life so poor and sorrowful.

SL : My life is so bad, I hate this life, God.

TL : Hidupku sangat buruk, aku benci hidup ini, Tuhan.

In this utterance, Liz tries to speak with God. Many problems come to her life. She thought that her marriage with Felipe is not save anymore. This utterance can be categorized into expressive utterance that is complaining. Liz seems that she is dejected of her life. This utterance is translated literally. The words in SL are translated literally in TL.

b. Code: 03-EPL

\section{Context:}

In a cocktail party with her friends, Liz met some new friends. She found her spirit in her life. Then, in her praying, she expressed her feeling to God.

SL : Hello, God. How are you? I'm Liz. It's nice to meet you.

TL : Halo Tuhan. Apa kabar? Saya Liz. Senang bertemu denganmu. 
As a woman trying to defend her marriage, a strong struggle to make the life marriage and carrier is balance has been done by Liz. In her praying, he tries to speak with God as a friend. This expressive utterance is a categorized into greeting. It is translated literally into target language since each word has its equivalent.

c. Code: $22-\mathrm{EPL}$

Context:

Liz was having a close conversation with her husband. She apologized to her husband that she could not continue their marriage. Liz thought that her husband would always be with her, indulging her whims forever.

SL : I'm sorry.

TL : Saya minta maaf.

Liz and Steven realized that many problems came to their marriage life and make them inconvenient. Liz apologized to her husband that she could not continue their marriage. This utterance is a kind of expressive utterance namely apologizing. The utterance is translated by using literal translation since every word has their own equivalence.

\subsubsection{Reduction}

Reduction is a translation technique which eliminates the information in source language. Information compaction is conducted should not alter the text of the message in the source language.

a. Code: 09-EPL

Context:

Liz is asked whether she loves Ian or not. Then Liz expressed her praise about Ian.

SL : He's attractive, intelligent. It's been long time since I thought about liking anybody.

TL : Dia menarik, cerdas. Sudah lama sekali sejak saya menyenangi seseorang.

This utterance is a kind of expressive utterances, that is praising. It shows that Liz praises Ian. She really admires Ian. She praises that Ian is an attractive and intelligent man. It is clearly to be seen from the word attractive and intelligent. This utterance is translated by using reduction techniques and literal translation. From the first; "He's attractive, intelligent." Is translated literally. Each word has its equivalent. However, there is information compaction found in the word 'thought about' is not translated in TL.

b. Code: 19-EPL

Context:

A man waked Liz up before she arrived in Venice. The man rubbed his eyes, looked at her closely. He called Liz cute. It made Liz shy and thanks to his attention

SL : A thousand thanks.

TL : Terima kasih.

Liz's utterance above is a kind of expressive utterance that is thanking. From this utterance, it can be identified that reduction technique is applied here. It can be clearly seen from SL utterance, the word thousand is not translated. It is directly translated become 'terima kasih'. 


\subsubsection{Transposition}

Transposition changes the grammatical categories of the SL into TL. This technique is commonly used because there is different grammar between SL and TL, such as replacing the words become phrases. Here are some examples:

a. Code: 25-EPL

Context:

Liz goes home to Felipe. Arriving at Felipe's house, her phone rang. It was from Wayan. She wanted to know Liz's condition. Then Liz tells that she was fine. She felt flattered.

SL : You are a good friend to me.

TL : Kamu teman baik saya.

This Liz's expressive utterances is called praising. It can be identified from the words 'good' uttered by Liz to Wayan. While smiling Liz expressed her admiration to Wayan. This utterance is translated by using transposition technique. Transposition is a kind of translation techniques that changes the grammatical elements from SL to Tl. In this case is the word 'me' in SL is changed into possessive form in TL.

b. Code: $30-E P L$

Context:

Liz tells Iva about her problems faced with her husband, also about her divorce.

SL : I wish I could write a petition to God, asking for this thing to end.

TL : Saya berharap saya dapat menulis sebuah petisi kepada Tuhan, memintanya untuk mengakhiri semua ini.

This utterance is translated by using transposition technique since there is a grammatical change occurred. It is shown by the clause 'asking for this thing to end' is translated into 'memintanya untuk mengakhiri semua ini.' The word 'end is changed grammatically.

\subsubsection{Modulation}

In translation, modulation is a technique generally applied. It replaces the focus or point of view or the cognitive aspect existed in SL. Below are the example of application of modulation technique.

Code: 27-EPL

Context:

Liz was looking at the beautiful scenery in Bali. She felt piece and calm down. She had a habit of imaging future and digging her pasts while seeing a lovely scenery.

SL : It's so beautiful here. I want to come back here someday.

TL : Disini sangat indah! Saya ingin kembali lagi ke sini suatu hari nanti!

This is an expressive utterance, that is praising. Liz expresses that she admires the scenery much. This utterance is translated using modulation technique. Modulation is a technique in which the focus of sentence is changed. It is shown from the utterance in SL "It's so beautiful here." Is translated into TL "Disini sangat indah!" it is clearly to be seen the focus of utterance is changed. The word 'It' in SL becomes "here' in TL. 


\subsection{Translation Quality Assessment}

The quality of translation is determined by three elements such as accuracy, acceptance, and readability. Based on the results of assessments by the rater and researcher, there are 33 data $(90 \%)$ categorized into accurate translations, 2 data (10\%) are less accurate, and 1 data (5\%) are not accurate. For acceptability, it is found that 35 data (95\%) are known as acceptable and 1 data $(5 \%)$ are indicated less acceptable. Based on the third element, 20 data $(100 \%)$ found as readable or easy to understand. Some examples of a good translation about translation quality are below:

\subsubsection{Accuracy}

Based on the result of analysis, there are 34 accurate translations and 2 less accurate translations. Here are some examples of them.

\subsubsection{Accurate} translation

Most of the findings shows accurate translation. Below are some examples of accurate

a. Code: 22-EPL

Context:

Liz apologized to her husband that she could not continue their marriage. Liz thought that her husband would always be with her, indulging her whims forever but he wasn't.

SL : I'm sorry.

TL : Saya minta maaf,

This is an example of accurate translation. The utterance is translated by using literal technique. Based on the rater assessment, the score is 3. It can be assumed that the utterance is accurate. In addition, literal translation has a good effect in making an accurate translation.

b. Code: 13-EPL

Context:

Liz knows that her problem is hard. She tries to tell what she he feels to God in her praying.

SL : But I'm in serious trouble.

TL : Tapi saya mempunyai masalah yang sangat berat.

It is another example of accurate translation. This utterance is translated using transposition technique because there is a grammatical change found. However, the application of this technique doesn't make meaning distortion. Based on the rater assessment, the scale stated is 2,8 . In other words, this translation refers to accurate translation.

\subsubsection{Less Accurate}

From all 36 expressive utterances, there are 2 data considered as less accurate translation. A less accurate translation occurs because there are meaning distortion found. Below is the example of less accurate translation. 
Code: $16-\mathrm{EPL}$

\section{Context: W}

While crying in her praying, Liz tells all of her problems to God. She begins by expressing her apologizing for not being thankful to God.

SL : And I'm sorry I haven't ever spoken directly to you before but I do hope I have always expressed ample gratitude for all blessings that you've given me in my life.

TL : Dan saya mohon maaf karena saya tidak pernah mengatakan hal ini sebelumnya kepadaMu, tetapi saya selalu mengucapkan banyak terima kasih untuk semua berkat yang telah Engkau berikan pada saya dalam hidup ini.

This utterance is translated by using reduction technique. The two raters gave the 2,4 in scoring this utterance since there is some untranslated words that cause meaning distortion. It can be seen from the utterance that the words "I do hope" is not translated.

\subsubsection{Acceptability}

The result for acceptability, it is found that there are 35 utterances considered as acceptable translation and 1 utterance is known as less acceptable translation. Some examples are below:

\subsubsection{Acceptable}

Acceptable translation is indicated by the translation sounds natural and written in accordance with language regulations of TL. The words used are common and familiar to readers. There are 35 data considered as acceptable translation. An example is follows:

Code: 11-EPL

Context: Liz says thank you to her friend, Iva for her support. As her close friend, Iva always support Liz to achieve happiness.

SL : Thank you, Iva. I appreciate your support.

TL : Terima kasih Iva. Saya menghargai dukunganmu.

Datum number 11 is identified as an acceptable translation. The raters gave score for this utterance in scale 3, which means the translation is acceptable. Based on rater's assessment, the translation sounds common, familiar and appropriate with the culture of SL.

\subsubsection{Less Acceptable}

From 36 expressive utterances by Liz, there are 35 data considered as acceptable translation and 1 data of less acceptable translation. Below are the examples:

Code: 35-EPL

Context:

Liz tries to explain her problem to her mother.

SL : I wish I could be more like you, then I could have this love story with David.

TL : Saya berharap saya dapat sepertimu, sehingga saya dapat memiliki kisah cinta ini dengan David. 
This utterance is indicated as less acceptable translation. The score given to this utterance is 2 . It refers to less acceptable. The raters gave the same score 2 in scoring this data because it is still like translation, so does the researcher. This SL translated feels like awkward and inappropriate in language rules of TL. This utterance will be better if it is translated into, "Aku berharap bisa seperti ibu, sehingga dapat memiliki kisah cinta ini dengan David." The word 'saya' is changed into 'aku' dan 'mu' becomes 'ibu'. These changes appropriate with Indonesian grammatical and feels more natural in a dialog between a daughter and her mother.

\subsubsection{Readability}

After doing analysis, all of expressive utterances in Eat Pray Love movie are considered as readable translation. The two raters gave 3 in scoring the data. Readable translation means TL has appropriateness in sentence construction. Thus, TL can be easily read and understood. Besides, the sentence is arranged well. Below is the example of readable translation found:

Code: 13-EPL

Context:

Liz knows that her problem is hard. She tries to tell what she he feels to God in her praying.

SL : But I'm in serious trouble.

TL : Tapi saya mempunyai masalah yang sangat berat.

\section{Conclusion}

After obtaining findings and discussions, several conclusions are derived. There are 6 functions of expressive utterances found. They are praising, thanking, complaining, apologizing, wishing and greetings. Most of them are praising utterances. It is closely correlated with the story that Liz as the main character struggles to be a happy woman in the world even she has many very complicated problems to solve. Fortunately, she has good friends around her giving support strength. Related to the translation techniques used, there are 4 techniques applied such as literal translation, reduction, transposition, and modulation. Similar kind of expressive utterances sometimes has different techniques in translating it. For example, praising utterances found in this movie are translated by using reduction, literal, transposition, and modulation. Most of translation techniques applied has a good impact towards translation quality. Based on the result from the raters, the mean scale for accuracy is 2,97 for each factor of translation quality including acceptability, accuracy, and readability. Therefore, it can be concluded that Liz's expressive utterances in Eat Pray Love movie have succeeded in maintaining the theme of the story including its characterization in the Indonesian translation.

\section{References}

Eugene Nida and Charles Taber. (1974). The Theory and Practice of Translation. United Bible Societies.

Fitriana, I. (2013). IN EAT PRAY LOVE NOVEL AND By: Translation Analysis Of Directive Speech Acts In Eat Pray Love Novel And Its Translation Into Indonesia, 02(02), 13-28. https://doi.org/https://doi.org/10.20961/prasasti.v2i2.332

George Yule. (1996). Pragmatics (1st ed.). Oxford University Press. 
George Yule. (2006). The Study of Language 6th Edition (6th ed.). Cambridge University Press.

John R. Searle. (1974). An Essay in the Philosophy of Language New Ed Edition. Cambridge University Press.

M. Rudolf Nababan. (n.d.). Teori Menerjemah Bahasa Inggris. Pustaka Pelajar.

Molina, L., \& Albir, A. H. (2002). Translation techniques revisited: A dynamic and functionalist approach. Meta, 47(4), 498-512. https://doi.org/10.7202/008033ar

Nababan, M., Nuraeni, A., \& Sumardiono. (2012). Pengembangan Model Penilaian Kualitas Terjemahan. Kajian Linguistik Dan Sastra, 24(1), 39-57.

Newmark, P. (1988). A textbook of translation (1988th ed.). Prentice-Hall International in English.

Nuraeni. Ardiana. (n.d.). Perbandingan Terjemahan Tindak Tutur Mengeluh dalam Film Bad Boys II yang ditayangkan di stasiun televisi dan VCD. UNS.

Nugraha, H. (2019). Kualitas Terjemahan Tindak Tutur Ekspresif Dalam Novel Breaking Down (Awal Yang Baru) Karya Stephenie Meyer. Al-Tsaqafa: Jurnal Ilmiah Peradaban Islam, 16(1), 124-134. https://doi.org/10.15575/al-tsaqafa.v16i1.3919

(http://id.shvoong.com/books/movie-moviela/2172421-eat-pray-love-perjalananmencari/\#ixzz2TFe3Cv2C). 